\title{
Whence Philosophy of Biology?
}

\author{
Jason M. Byron
}

A consensus exists among contemporary philosophers of biology about the history of their field. According to the received view, mainstream philosophy of science in the 1930s, 40s, and 50s focused on physics and general epistemology, neglecting analyses of the 'special sciences', including biology. The subdiscipline of philosophy of biology emerged (and could only have emerged) after the decline of logical positivism in the 1960s and 70s. In this paper, I present bibliometric data from four major philosophy of science journals (Erkenntnis, Philosophy of Science, Synthese, and the British Journal for the Philosophy of Science), covering 1930-1959, which challenge this view.
1 Introduction
2 Methods
3 Results
4 Conclusion

\section{Introduction}

As a subdiscipline of philosophy of science, philosophy of biology is young. Philosophical discussion of various aspects of the living world is of course ancient. Scholars have been doing 'philosophy of biology', in this sense, from at least the time of Aristotle. But only in the 1980s and 90s did philosophers of science establish philosophy of biology as an academic field. ${ }^{1}$ For example, the first (partial) philosophy of biology journal, History and Philosophy of the Life Sciences, commenced publication only in 1979. Four others would follow: Biology and Philosophy (first published in 1986), Ludus Vitalis: Revista de Filosofía de las Ciencias

\footnotetext{
${ }^{1}$ General philosophy of science, in contrast, became a professional discipline by the late 1950s (Douglas [forthcoming]).
} 
de la Vida (in 1993), Jahrbuch für Geschichte und Theorie der Biologie (in 1994), and Studies in History and Philosophy of Biological and Biomedical Sciences (in 1998). The field's two professional associations are likewise recently founded: The International Society for History, Philosophy, and Social Studies of Biology (in 1989) and the Deutsche Gesellschaft für Geschichte und Theorie der Biologie (in 1991). The first generation of selfidentified philosophers of biology emerged during the 1960s and early 1970s. Morton Beckner ([1959]) and Marjorie Grene ([1959]; Grene and Mendelsohn [1976]) were first, followed by David Hull ([1964, 1969, 1974]), Michael Ruse ([1973]), Kenneth Schaffner ([1967a, 1967b]), and William Wimsatt ([1972]). ${ }^{2}$ Beckner's Biological Way of Thought ([1959]) and Hull’s Philosophy of Biological Science ([1974]) were especially influential. By the mid-1980s, a second generation of philosophers of biology ushered the field into a professional subdiscipline. That generation (from, roughly, the mid-1970s to the mid-1980s) included Ronald Amundson, John Beatty, Robert Brandon, Richard Burian, Lindley Darden, David Depew, John Dupré, James Griesemer, Philip Kitcher, Elisabeth Lloyd, Alexander Rosenberg, Elliott Sober, and Bruce Weber, among others.

The recent origins of philosophy of biology might suggest that philosophy of biology had been previously neglected by philosophers of science. Why else, one might ask, would philosophers of science have carved out a new professional niche devoted to the analysis of biology? Indeed, the first philosophy of biology textbooks claimed that their subject had been ignored by contemporary philosophers of science in favour of physics. Consider the following, taken from a few introductions:

One often finds philosophers remarking that the account of scientific methods and procedures drawn up by contemporary empiricists suffers from an undue preoccupation with the physical sciences. (Beckner [1959: v])

\footnotetext{
${ }^{2}$ See also Goudge ([1961]); Rensch ([1968]); Monod ([1970]); Ayala and Dobzhansky ([1974]).
} 
The author of a book on the philosophy of biology need offer no excuse for the subject he has chosen, since few areas of philosophy have been so neglected in the past fifty years. (Ruse [1973: 9])

The purpose of this volume will be to take a closer look at that area of science [biology] which has been passed over in the rapid extrapolation from physics to the social sciences. (Hull [1974: 6])

The philosophy of biology should move to the center of the philosophy of science-a place it has not been accorded since the time of Mach. Physics was the paradigm of science, and its shadow falls across contemporary philosophy of biology as well. (Cohen and Wartofsky [1976: v])

These statements were written by first-generation philosophers of biology. Together, they expressed the view that philosophy of biology had not fared well, at least vis-à-vis philosophy of physics, among philosophers of science at the time. The authors justified their projects as a remedy to that neglect. A similar view can be found in the textbooks published by second-generation philosophers of biology: ${ }^{3}$

In the last few decades many philosophers have turned their attention to biology to assess the adequacy of a philosophy of science that has been drawn from an almost exclusive examination and reconstruction of physics. (Rosenberg [1985: 13])

Nor is it a surprise that, in this century particularly, the philosophy of science has become almost a subdiscipline in itself. But this does not include the philosophy of biology — at least, it did not until very recently. Although the father of philosophy of science, Aristotle, was as much a biologist as a philosopher, the philosophers of science in the twentieth century have focused mainly on the physical sciences, and any spare effort has tended to be directed toward the social sciences. (Ruse [1988: 12])

Again, philosophers of biology claimed that philosophy of biology was not part of philosophy of science during its formative years as a discipline. The professionalization of philosophy of biology seems to have been fuelled, in part, by the conviction that philosophy of biology occupied a marginal position within early philosophy of science. But the rhetoric of return, to

\footnotetext{
${ }^{3}$ One finds less justificatory maneuvering in the introductions to philosophy of biology textbooks published after the late 1980s, perhaps because by then the field had attained a certain professional status and the authors felt no need to explicitly argue for the importance of biology in philosophy of science. See, for example, Sober ([1993]); Rosenberg ([1994]); Mahner and Bunge ([1997]); Hull and Ruse ([1998]); Sterelny and Griffiths ([1999]). Nevertheless, the received view of the history of philosophy of biology continues to be told—just not in textbooks (see Callebaut [1993]; Wolters [1999]).
} 
Mach or even Aristotle, suggests that philosophers of biology felt their marginalized situation was recent. Logical positivism, in particular, was often identified as the culprit. Betty

Smocovitis, for example, suggests that contemporary philosophy of biology emerged 'out of the 1960s antireductionist movements in biology and antipositivist movements in philosophy'—while also acknowledging the need for further study (Smocovitis [1996: 105]). Consider the following comments from Werner Callebaut, Elliott Sober, and Alexander Rosenberg:

Sober: The positivists took as one of their main paradigms of a scientific theory Einstein's theory of relativity, and their philosophical problems and the views that they developed about them were often keyed to that single theory. To a lesser degree they considered quantum mechanics. But issues in biology did not interest them very much; specific issues that are internal to psychological theory matter to them almost not at all.

Rosenberg: Well, if you look at the Encyclopedia of Unified Science, even back in the thirties and forties there were articles on economics and biology and other disciplines.

Callebaut: But in retrospect we can say it was basically a philosophy of physics (of a rather peculiar kind). The 'application' of logical-empiricist views to, say, biologyI'm thinking of the work of someone like Woodger — now makes us smile-or cry. The thing may have been intended as general theory, but the methodology that was put forward

Rosenberg: was drawn exclusively from physics

Callebaut: and other fields had to fit that model. You agree with that. So a fundamental problem of older work in philosophy of biology was that to the extent it was done by people working in the positivist tradition, like Woodger, they had a very difficult time.

Rosenberg: Yes, absolutely.

Sober: What has happened since the demise of positivism is that philosophers have gotten interested in the details of particular scientific theories. In the 1930s, philosophers of physics were interested in relativity theory and quantum theory and that has continued to the present. Only more recently have philosophers of biology really gotten into the details of evolutionary theory and other theories in biology; and similarly with philosophy of psychology, I think. The demise of positivism allowed this proliferation to occur, because it was no longer necessarily a given that all 
scientific theories were the same; there could be problems internal to a scientific theory that might be of philosophical interest. (Callebaut [1993: 73-74]) ${ }^{4}$

Here, the emergence of philosophy of biology is explicitly tied to the putative fall of logical positivism after the 1950s. And that position, that logical positivism was hostile to philosophy of biology, is well entrenched among contemporary philosophers of biology.

Why might this be? If we consider the history of philosophy of science literature, we find little to refute the received view of the origins of philosophy of biology and its relation to general philosophy of science. Standard historical treatments of logical positivism focus on the roles of physics and the social sciences in the development of philosophy of science (see, for example, Suppe [1977: 3-241]; Friedman [1999]). No mention is made of biology in those works, and that lacuna might suggest to some readers that the biological sciences did not contribute to the early development of philosophy of science in the 1930s, 40s, and 50s. Consider, too, general philosophy of science textbooks and key monographs published before the 1970s (that is, during the 'first wave' of philosophy of biology). Almost all excluded biology in their explications of philosophical issues; a few discussed biology, but only very briefly (see, for example, Bergmann [1957]; Braithwaite [1953]; Frank [1949]; Goodman [1954]; Hanson [1958]; Hempel [1965, 1966]; Hesse [1966]; Madden [1960]; Nagel [1961]; Pap [1962]; Popper [1959, 1962]; Salmon [1967]; Smart [1968]; Toulmin [1953]; Wartofsky [1968]). So the received view, even if inaccurate (as I shall argue), is not altogether implausible.

Despite its apparently widespread acceptance, the received view of the historical origins of philosophy of biology as a subdiscipline of philosophy of science has never been systematically examined. The only historical treatment of philosophy of biology, Grene and Depew’s The Philosophy of Biology: An Episodic History ([2004]), reconstructs the

\footnotetext{
${ }^{4}$ Comments were reconstructed by Callebaut to appear as an extended dialogue; however, these statements were expressed individually, and independently, in interviews conducted by him (see Callebaut [1993]).
} 
‘philosophies of biology’ of various scholars, such as Aristotle, Descartes, and Kant, but it does not examine the emergence of philosophy of biology as an academic field. ${ }^{5}$ That work remains to be done.

In what follows, I attempt a first-pass, rough-grain analysis of some relevant evidence. My ultimate aim is to determine the place of philosophy of biology within early philosophy of science, and I begin by examining founding journals of philosophy of science: Erkenntnis (first published in 1930), Philosophy of Science (in 1934), Synthese (in 1936), and the British Journal for the Philosophy of Science (in 1950). I am especially keen to evaluate the contributions of philosophy of biology to philosophy of science during the 1930s, 40s, and 50s — when philosophers of science established for themselves what questions, methods, concepts, and ideas would be central to their discipline, as distinct from scientific philosophy and analysis (Giere [1996]). Future work must flesh out the details and circumscribe the relevance of the evidence I present. But the time is ripe for a broad sketch of important trends.

\section{Methods}

To assess the role and influence of philosophy of biology in the early development of philosophy of science I analyzed the contents of the first philosophy of science journals, published between 1930 and 1959: Erkenntnis (vol. 1 [1930-1931] to vol. 8 [1939-1940]), Philosophy of Science (henceforth, Phil Sci; vol. 1 [1934] to vol. 26 [1959]), Synthese (vol. 1 [1936] to vol. 11 [1959]), and the British Journal for the Philosophy of Science (henceforth, BJPS; vol. 1 [1950-1951] to vol. 10 [1959-1960]). ${ }^{6}$ Although other periodicals published work in philosophy of science during this period, none (with the exception of Minnesota Studies in the Philosophy of Science, which published just two volumes) published

\footnotetext{
${ }^{5}$ See also Hull ([forthcoming]).

${ }^{6}$ Vol. 8 of Erkenntnis was published as the Journal of Unified Science (Erkenntnis)..
} 
philosophy of science exclusively, and, consequently, none reliably tracks the career of philosophy of science as a discipline.

I began by counting the total number of articles published in each journal during the thirty-year period. I included only full articles ('Abhandlungen’ in Erkenntnis) and full conference proceedings ('Berichte', 'Referate', or 'Vorträge' in Erkenntnis). Articles with multiple parts were counted separately, so long as they appeared separately in the table of contents or, when there was no table of contents, in separate issues or non-contiguously in the same issue.

Next, I counted the total number of philosophy of biology articles published in each journal (among those counted as full articles). I excluded articles on behaviourism, phenomenology, philosophy of mind, psychoanalysis, and psychology. Much attention has already been paid to psychology and the social sciences in the history of philosophy of science literature. ${ }^{7}$ Here, I wanted to isolate articles on such topics as bioethics, botany, cytology, developmental biology, cognitive science, ethology, evolution, medicine, neurophysiology, and zoology. I carefully examined all articles that seemed to straddle philosophy of biology and philosophy of mind to better classify their contents. A few were true hybrids (those, for example, on the evolution of thinking or on the information-carrying capacities of particular neurons). I included them as philosophy of biology and marked them with an asterisk in the online supplemental material. ${ }^{8}$

\section{Results}

A total of 1547 articles were published in Erkenntnis, Phil Sci, Synthese, and BJPS between 1930 and 1959. Of these 137, or 8.86\%, were devoted to philosophy of biology (see online

\footnotetext{
${ }^{7}$ The influence of Gestalt psychology and Otto Neurath’s political philosophy, to name but two examples, has been well studied.

${ }^{8}$ Supplemental material is available at <http://www.pitt.edu/ jmb165/Suppl.html>.
} 
supplemental material). Each year, an average of $9.6 \%$ of the total number published was on philosophy of biology (95\% CI: 7.6\%-11.7\%). The breakdown across journals is as follows: 178 articles were published in Erkenntnis (with 18, or 10.1\%, on philosophy of biology), 739 in Phil Sci (with 66, or 8.9\%, on philosophy of biology), 474 in Synthese (with 32, or 6.8\%, on philosophy of biology), and 156 in BJPS (with 21, or 13.5\%, on philosophy of biology). I computed a linear regression on the data set, which showed no significant change over time (see Fig. 1).

Fig. 1: Philosophy of biology articles published per year (as a percentage of total)

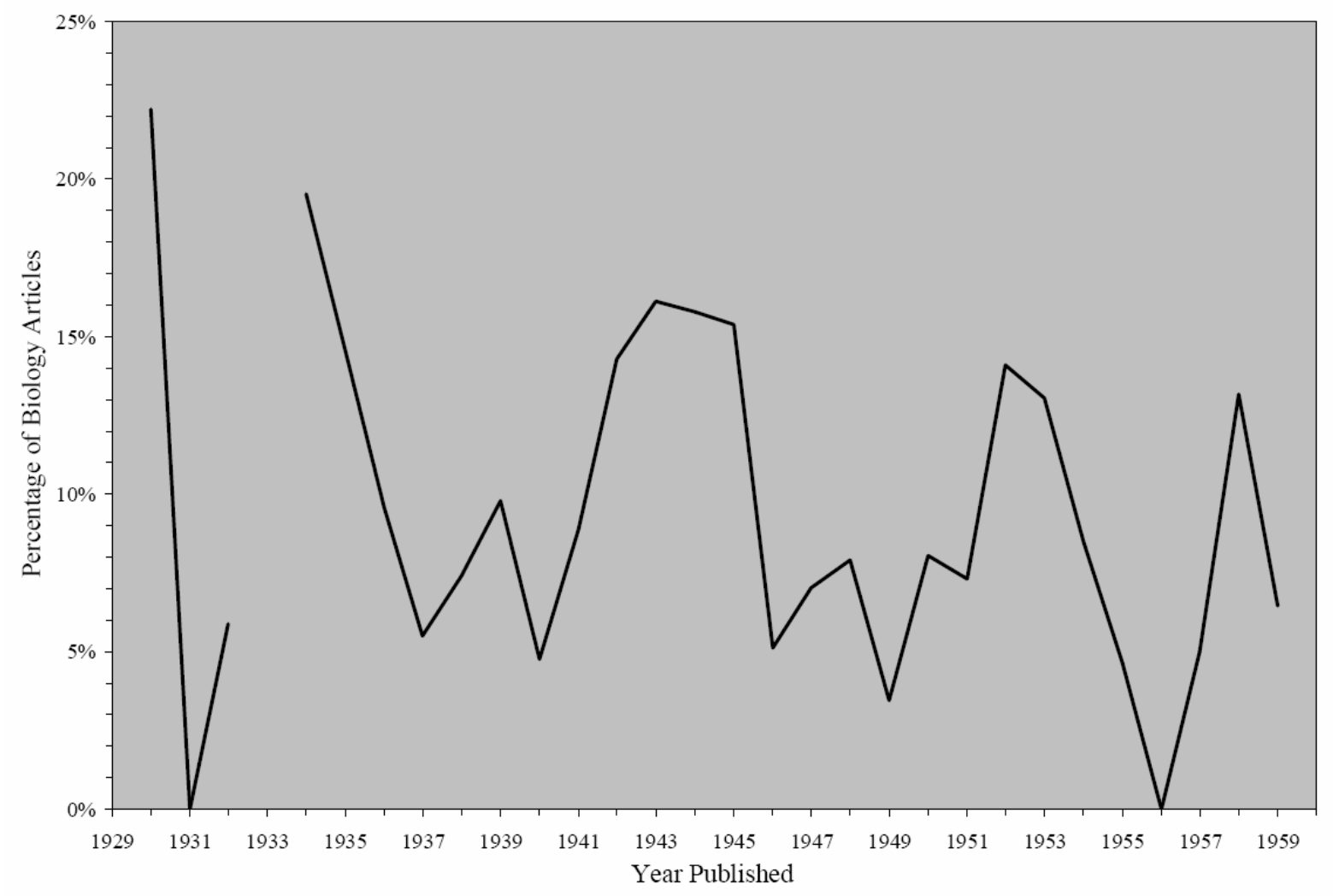

These results strongly refute the hypothesis, so integral to the received view, that philosophy of biology was excluded during the formative years of philosophy of science. Nevertheless, even if one acknowledges that philosophy of biology was not entirely neglected by early philosophers of science, there is a common belief that the kind of work they 
published was something other than 'real', or legitimate, philosophy of biology. That is, biology was either forced by early philosophers of science into a philosophical framework derived from physics or was run out of the realm of science altogether. Michael Ruse, for example, wrote the following in 1988:

What little attention has been paid to biology [by twentieth-century philosophers of science] has been generally directed to one extreme or another. At one end of the spectrum we have those who were overly impressed by the turn-of-the-century formalisms of the logicians and mathematicians, and who wanted to do likewise for biology. Since they-especially their leader J. H. Woodger-were simultaneously empiricists of the most naively dogmatic kind, their efforts tended to go unread. At the other end of the spectrum we have those who feared and loathed materialism, and who were determined to prove that an understanding of organisms demands reference to vital forces or spirits-élans vitaux or entelechies-forever beyond the grasp of conventional science. (Ruse [1988: 1-2])

Having, as we now do, a complete list of biology articles published in philosophy of science journals from 1930-1959, we are well-positioned to assess Ruse’s charge. Indeed, we do find several articles that deal with vitalism-mechanism debates, and one or two authors advocated a 'vitalist' position. ${ }^{9}$ Moreover, we find several articles in the 'formalist' vein, which attempt to analyze biology along the lines of physics. However, this is not nearly the whole story. Even a cursory glance through the list reveals a large number of articles that any contemporary philosopher of biology would recognize as 'real' philosophy of biology.

Consider the following titles, listed in chronological order:

- Das Biologische Individuum (1930-1931)

- Die Methodologischen Grundlagen der Biologie (1932-1933)

- Kausalität, Biologie und Psychologie (1934)

- Indeterminism and Natural Selection (1934)

- The Views of Haeckel in the Light of Genetics (1934)

- Structure, Function and Growth (1935)

- A Critique of the Species Concept in Biology (1935)

- Prikkelverschijnselen bij Plant, Dier en Mensch, I-III (1936)

- Some Principles of Causal Analysis in Genetics (1937)

\footnotetext{
${ }^{9}$ Ruse's characterization of neo-vitalism as demanding explanatory recourse to forces 'forever beyond the grasp of conventional science' is misleading. However, for the purposes of this paper, it suffices to show that early philosophy of biology was not much concerned with neo-vitalism, whatever that doctrine actually entailed. For more a more nuanced analysis of the mechanism-vitalism debates published in Philosophy of Science, see Byron ([forthcoming]).
} 
- De Tegenwoordige Stand van de Evolutie-Gedachte in de Ethnologie (1938)

- Causaliteit en Causale Structuren: De Beteekenis van Deze Begrippen Voor de Wetenschap van Het Leven (1939)

- What is a Gene? (1939)

- History and Biological Evolution (1940)

- Biological Causation (1940)

- Diffusion and Biological Membrane Permeability, II (1941)

- Geometry and Dynamics of Populations (1941)

- Protoplasmic Activity (1941)

- The Problem of Synthesis in Biology (1942)

- A Biological Basis for Ethics (1942)

- Vegetation as an Object of Study (1942)

- The Theoretical Basis of Biotypology (1943)

- The Role of Catalysis in Biological Causation (1943)

- The Neurodynamics of Behavior: A Phylobiological Foreword (1943)

- Organization (1944)

- Levels of Research in the Biological Sciences (1945)

- Chemistry and Evolution (1945)

- A Theory on Causal Factors in the Origin of Life (1945)

- Types and Similitudes: An Enquiry into the Logic of Comparative Anatomy (1946)

- Objekt und Methode in der Biologie (1947-1948)

- Einheit und Methode in der Biologie (1947-1948)

- The Unity of the Morphological and Functional Aspects of Living Matter (1947)

- The Effect of the Concept of Evolution on Scientific Methodology (1948)

- The Concept of Evolution (1948-1949)

- Some Aspects of Theoretical Biology (1948)

- The Logical Analysis of Kinship (1949)

- An Analysis of Some Concepts and Terms in Vegetation Study or Phytocenology (1950-1951)

- Gradation of Language in Biological Systematics (1950-1951)

- Causation and Explanation in Theoretical Biology (1951)

- Hans Selye and a Unitary Conception of Disease (1952)

- Information in the Head (1953)

- The Information Capacity of the Human Ear and of the Cochlear Nerve (1953)

- What Do We Mean by ‘Inborn’? (1953)

- D’arcy Thompson: His Conception of the Living Body (1953)

- An Account of Recent Biological Methodology: Causal Law and Transplanar Analysis (1953)

- The Evolution of Thinking (1954)

- Theory of Integrative Levels (1954)

- What is Disease? (1954)

- The Place of Historical Statements in Biology (1957)

- Ethics and Esthetics on a Biological Basis (1958)

- Causal Explanations in Natural History (1958)

- The Evolution of a Human Nature (1959)

- Origin Explanations and the Origin of Life (1959)

- On Deciding Whether Protistans are Cells (1959) 
Those titles, 55 in all, represent $40.2 \%$ of the total philosophy of biology articles published. And many of the titles I excluded from this list dealt, not with vitalism or formal analysis, but with cybernetics and other topics rarely seen in contemporary philosophy of biology journals. Philosophy of science journals, therefore, were publishing 'real’ philosophy of biology articles—-many of them—-throughout the 1930s, 40s, and 50s.

To summarize: nearly $10 \%$ of the articles published each year in the four professional philosophy of science journals from 1930 to 1959 were in philosophy of biology. Moreover, this rate of publication was steady with no significant change over the course of 30 years (at most, there was a slight tapering off of philosophy of biology articles during the 1950s, but this is not a statistically relevant trend). While a minority of these articles concerned issues that we now consider dated, such as logical axiomatisation and vitalism, nearly half addressed subjects recognizable as topical today. But present relevance is neither here nor there with regard to the fundamental historical point; these data show that throughout the formative period of the professionalization of philosophy of science, philosophy of biology was an active part of the field.

\section{Conclusions}

Many have argued that, despite its rhetoric of scientific unity and pluralism, logical positivism in fact neglected the analysis of biology, focusing instead on the hierarchical termini of physics and, to a much lesser extent, the social sciences (see, for example, Wolters [1999]). The emergence of a professional field of philosophy of biology was only made possible, according to this view, with of the demise of logical positivism. ${ }^{10}$ However, the

\footnotetext{
${ }^{10}$ Possibly logical positivism never died (Creath [1995]). For the purposes of my argument, it does not matter. Whatever the fate of logical positivism was, the rise of the profession of philosophy of biology should not be explained by a putative decline of logical positivism in the 1960s and 70s, as Sober and Rosenberg do (Callebaut [1993: 73-74]). Logical positivism did not suppress philosophy of biology in the first place.
} 
results of my preliminary analysis suggest something is very wrong with this story. Philosophy of biology articles appeared frequently and throughout the 1930s, 40s, and 50s in the four major philosophy of science journals: Erkenntnis, Philosophy of Science, Synthese, and the British Journal for the Philosophy of Science. Those articles, moreover, were not simply vitalist or formalist; 'real' philosophy of biology (as contemporary scholars might interpret it) was being published. In addition, biologists sat on the editorial boards of Phil Sci, Synthese, and BJPS every year they were published, from 1930-1959. Clearly, philosophers of science were interested in biological issues and made them a central part of the discipline.

Thus, while it is doubtless true that the '1960s antireductionist movements in biology and antipositivist movements in philosophy’ shaped contemporary philosophy of biology, those movements do not explain its origins as a subdiscipline of philosophy of science. Philosophy of biology did not require antipositivism, in particular, to thrive. Logical positivists were long interested in 'real' philosophy of biology, and biologists and philosophers steadily published work in philosophy of biology throughout the period I examined. If philosophy of biology was in bad shape by the late 1960s, as David Hull ([1969]) argued, its ills cannot be traced to any neglect by logical positivists in the 1930s, 40s, and 50s. Rather, the exclusion of philosophy of biology from philosophy of science seems to have occurred only after the professionalization of philosophy of science in the late 1950s and 60s, when biologists (and other scientists) were displaced by professional ‘philosophers of science’ in the relevant journals (see Hardcastle and Richardson [2003]; Howard [2003]; Reisch [2005]). The rise of philosophy of biology as its own subdiscipline during the 1970s, 80s, and 90s may be better explained as a reaction to this displacementand the abstraction away from science that generally occurred during the 1950s and 60s. The return to the science urged by and taken up with a vengeance by philosophers of biology (among many others) in the 1960s, 70s, and 80s gave the burgeoning field its problematic. It 
represented a broader return to — not a reaction against—-the philosophy of science of the 1930s, 40s, and 50s, one in which philosophers and scientists together set the problematic of philosophy of science. $^{11}$

\section{Acknowledgements}

For insightful comments on previous drafts of this paper, I thank Ron Amundson, Jordi Cat, Richard Creath, Lindley Darden, Melinda Fagan, Sandy Gliboff, Jane Maienschein, George Reisch, Alan Richardson, Michael Ruse, Jutta Schickore, and Brad Wray. Special thanks to David Hull, Betty Smocovitis, and Lisa Lloyd for detailed criticisms and advice.

Department of History and Philosophy of Science University of Pittsburgh 1017 Cathedral of Learning Pittsburgh, PA 15260

\section{References}

Ayala, F. J. and Dobzhansky, T. G. (eds.) [1974]: Studies in the Philosophy of Biology: Reduction and Related Problems, London: Macmillan.

Beckner, M. [1959]: The Biological Way of Thought, New York: Columbia University Press.

Bergmann, G. [1957]: Philosophy of Science, Madison: University of Wisconsin Press.

Braithwaite, R. B. [1953]: Scientific Explanation: A Study of the Function of Theory, Probability, and Law in Science, New York: Cambridge University Press.

Byron, J. M. [forthcoming]: 'Physics, Biology, and their Logical Analysis, 1934-1959: Mechanism-Vitalism Debates as a Locus of Interaction', unpublished MS.

\footnotetext{
${ }^{11}$ See, e.g., Hofer ([2002]) on philosophy of biology within the Vienna Circle.
} 
Callebaut, W. (ed.) [1993]: Taking the Naturalistic Turn: Or, How Real Philosophy of Science Is Done, Chicago: University of Chicago Press.

Cohen, R. S. and Wartofsky, M. W. [1976]: 'Preface’ to Grene and Mendelsohn ([1976]).

Creath, R. [1995]: ‘Are Dinosaurs Extinct?’ Foundations of Science, 2, pp. 285-297.

Douglas, H. [forthcoming]: 'Acceptable Topics in the Philosophy of Science: Establishing a Discipline’, unpublished MS.

Frank, P. [1949]: Modern Science and Its Philosophy, Cambridge, Mass.: Harvard University Press.

Friedman, M. [1999]: Reconsidering Logical Positivism, New York: Cambridge University Press.

Giere, R. N. [1996]: 'From Wissenschaftliche Philosophie to Philosophy of Science’, in R. N. Giere and A. W. Richardson (eds.), Origins of Logical Empiricism, Minneapolis: University of Minnesota Press, 335-354.

Goodman, N. [1954]: Fact, Fiction, and Forecast, Cambridge, Mass.: Harvard University Press.

Goudge, T. A. [1961]: The Ascent of Life: A Philosophical Study of the Theory of Evolution, Toronto: University of Toronto Press.

Grene, M. [1959]: 'Two Evolutionary Theories, I-II’, British Journal for the Philosophy of Science, 9, pp. 110-127, 185-193.

Grene, M. G. and Depew, D. J. [2004]: The Philosophy of Biology: An Episodic History, New York: Cambridge University Press.

Grene, M. G. and Mendelsohn, E. (eds.) [1976]: Topics in the Philosophy of Biology, Dordrecht: D. Reidel.

Hanson, N. R. [1958]: Patterns of Discovery: An Inquiry into the Conceptual Foundations of Science, New York: Cambridge University Press. 
Hardcastle, G. L. and Richardson, A. W. (eds.) [2003]: Logical Empiricism in North America, Minneapolis: University of Minnesota Press.

Hempel, C. G. [1965]: Aspects of Scientific Explanation, and Other Essays in the Philosophy of Science, New York: Free Press.

Hempel, C. G. [1966]: Philosophy of Natural Science, Englewood Cliffs, N.J.: Prentice-Hall.

Hesse, M. B. [1966]: Models and Analogies in Science, Notre Dame, Ind.: University of Notre Dame Press.

Hofer, V. [2002]: 'Philosophy of Biology around the Vienna Circle: Ludwig Von Bertalanffy, Joseph Henry Woodger, and Philipp Frank’, in M. Heidelberger and F. Stadler (eds.), History of Philosophy of Science: New Trends and Perspectives, Dordrecht: Kluwer Academic, pp. 325-333.

Howard, D. [2003]: ‘Two Left Turns Make a Right: On the Curious Political Career of North American Philosophy of Science at Midcentury’, in G. L. Hardcastle and A. W. Richardson ([2003]), pp. 25-93.

Hull, D. L. [1964]: ‘The Metaphysics of Evolution’, British Journal for the History of Science, 3, pp. 309-337.

Hull, D. L. [1969]: 'What Philosophy of Biology Is Not’, Synthese, 20, pp. 157-184.

Hull, D. L. [1974]: Philosophy of Biological Science, Englewood Cliffs, N.J.: Prentice-Hall.

Hull, D. L. [forthcoming]: 'The history of philosophy of biology', in M. Ruse (ed.), Oxford Handbook of the Philosophy of Biology, New York: Oxford University Press.

Hull, D. L. and Ruse, M. (eds.) [1998]: The Philosophy of Biology, New York: Oxford University Press.

Madden, E. H. [1960]: The Structure of Scientific Thought: An Introduction to Philosophy of Science, Boston: Houghton Mifflin.

Mahner, M. and Bunge, M. A. [1997]: Foundations of Biophilosophy, New York: Springer. 
Monod, J. [1970]: Le Hasard et la Nécessité: Essai sur la Philosophie Naturelle de la Biologie Moderne, Paris: Éditions du Seuil.

Nagel, E. [1961]: The Structure of Science: Problems in the Logic of Scientific Explanation, New York: Harcourt.

Pap, A. [1962]: An Introduction to the Philosophy of Science, New York: Free Press.

Popper, K. R. [1959]: The Logic of Scientific Discovery, New York: Basic Books.

Popper, K. R. [1962]: Conjectures and Refutations: The Growth of Scientific Knowledge, New York: Basic Books.

Reisch, G. A. [2005]: How the Cold War Transformed Philosophy of Science: To the Icy Slopes of Logic, New York: Cambridge University Press.

Rensch, B. [1968]: Biophilosophie auf erkenntnistheoretischer Grundlage, Stuttgart: G. Fischer.

Rosenberg, A. [1985]: The Structure of Biological Science, New York: Cambridge University Press.

Rosenberg, A. [1994]: Instrumental Biology, or the Disunity of Science, Chicago: University of Chicago Press.

Ruse, M. [1973]: The Philosophy of Biology, London: Hutchinson.

Ruse, M. [1988]: Philosophy of Biology Today, Albany: State University of New York Press.

Salmon, W. C. [1967]: The Foundations of Scientific Inference, Pittsburgh: University of Pittsburgh Press.

Schaffner, K. F. [1967a]: ‘Approaches to Reduction’, Philosophy of Science, 34, pp. 137-147.

Schaffner, K.F. [1967b]: ‘Antireductionism and Molecular Biology’, Science, 157, pp. 644647.

Smart, J. J. C. [1968]: Between Science and Philosophy: An Introduction to the Philosophy of Science, New York: Random House. 
Smocovitis, V. B. [1996]: Unifying Biology: The Evolutionary Synthesis and Evolutionary Biology, Princeton, N.J.: Princeton University Press.

Sober, E. [1993]: Philosophy of Biology, Boulder, Colo.: Westview Press.

Sterelny, K. and Griffiths, P. E. [1999]: Sex and Death: An Introduction to Philosophy of Biology, Chicago: University of Chicago Press.

Suppe, F. (ed.) [1977]: The Structure of Scientific Theories, Urbana: University of Illinois Press.

Toulmin, S. E. [1953]: The Philosophy of Science: An Introduction, London: Hutchinson.

Wartofsky, M. W. [1968]: Conceptual Foundations of Scientific Thought: An Introduction to the Philosophy of Science, New York: Macmillan.

Wimsatt, W. C. [1972]: ‘Teleology and the Logical Structure of Function Statements’, Studies in the History and Philosophy of Science, 3, pp. 1-80.

Wolters, G. [1999]: ‘Wrongful Life: Logico-Empiricist Philosophy of Biology’, in M. C. Galavotti and A. Pagnini (eds.), Experience, Reality, and Scientific Explanation: Essays in Honor of Merrilee and Wesley Salmon, Dordecht: Kluwer, 187-208. 